\title{
Corticotropin-releasing factor receptors and stress-related alterations of gut motor function
}

\author{
Yvette Taché ${ }^{1}$ and Bruno Bonaz ${ }^{2}$
}

\begin{abstract}
${ }^{1}$ CURE: Digestive Diseases Research Center, and Center for Neurovisceral Sciences \& Women's Health, Department of Medicine, Division of Digestive Diseases, UCLA, and VA Greater Los Angeles Healthcare System, Los Angeles, California, USA. 2Groupe d'Etude du Stress et des Interactions Neuro-Digestives (EA3744), Department of Gastroenterology and Hepatology, Grenoble Faculty of Medicine and Hospital, Grenoble, France.
\end{abstract}

\begin{abstract}
Over the past few decades, corticotropin-releasing factor (CRF) signaling pathways have been shown to be the main coordinators of the endocrine, behavioral, and immune responses to stress. Emerging evidence also links the activation of CRF receptors type 1 and type 2 with stress-related alterations of gut motor function. Here, we review the role of CRF receptors in both the brain and the gut as part of key mechanisms through which various stressors impact propulsive activity of the gastrointestinal system. We also examine how these mechanisms translate into the development of new approaches for irritable bowel syndrome, a multifactorial disorder for which stress has been implicated in the pathophysiology.
\end{abstract}

\section{Stress and gut motor function}

A real or perceived threat to the homeostasis of mammalian organisms, originating internally or externally, triggers adaptive stress responses that affect behavior, as well as endocrine, immune, autonomic, and visceral functions $(1,2)$. Regarding effects in visceral functions in particular, early seminal investigations reported by Cannon and by Almy and colleagues provided clear evidence that emotional stress impacts gastric and colonic motor activity in healthy volunteers and cats $(3,4)$. Subsequent studies established that delayed emptying of the stomach is the most common response evoked by various acute stressors in both experimental animals and healthy human subjects (5). By contrast, in the colon, various stressors (including anxiety, dichotomous listening, fear, intermittent hand immersion in cold water, and stressful interviews) increase colonic motility in healthy subjects (5). Similarly, in rodents and dogs, stressors as diverse as open-field test, fear conditioning, loud sound, restraint, cold exposure, water avoidance, inescapable foot or tail shocks, and increased levels of cytokines induced by endotoxins stimulate propulsive colonic motor function $(2,5-7)$. The autonomic nervous system provides a peripheral neuronal network by which the effects of stress can be rapidly imposed on gut function. These are mediated through the sympathetic, and vagal and pelvic parasympathetic innervation of the enteric nervous system embedded into the muscular layers of the gut (8).

It is becoming increasingly recognized that these interconnected brain-gut neuronal pathways activated during stress have relevance in the pathophysiology of functional bowel disorders (9-11). In particular, various stressors in the form of early life trauma, sexual abuse, maternal neglect, fear conditioning, lifethreatening events, and enteric infection have an important role

Nonstandard abbreviations used: antisauvagine-30, $\left[\mathrm{D}-\mathrm{Phe}^{11}, \mathrm{His}^{12}\right]$ sauvagine $_{11-40}$; astressin, cyclo(30-33) [D-Phe $\left.{ }^{12}, \mathrm{Nle}^{21,38}, \mathrm{Glu}^{30}, \mathrm{Lys}^{33}\right] \mathrm{Ac}-\mathrm{CRF}_{9-41}$; astressin-B,

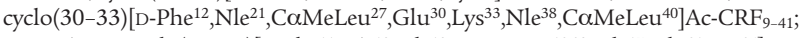
$\operatorname{astressin}_{2}-\mathrm{B}, \mathrm{cyclo}(31-34)\left[\mathrm{D}-\mathrm{Phe}^{11}{ }^{1} \mathrm{His}^{12}, \mathrm{Nle}^{12}, \mathrm{CaMeLeu}{ }^{13,39}, \mathrm{Nle}^{17}, \mathrm{Glu}^{31}{ }^{1} \mathrm{Lys}^{34}\right] \mathrm{Ac}^{-}$ sauvagine ${ }_{8-40}$; $\mathrm{CRF}$, corticotropin-releasing factor; $\mathrm{CRF}_{1}, \mathrm{CRF}$ receptor type $1 ; \mathrm{CRF}_{2}$, CRF receptor type 2; CSF, cerebrospinal fluid; $\mathrm{D}-\mathrm{Phe}^{12} \mathrm{CRF}_{12-41}$,

$\left[\mathrm{D}-\mathrm{Phe}^{12}, \mathrm{Nle}^{21,38}, \mathrm{C} \alpha \mathrm{MeLeu}^{37}\right] \mathrm{CRF}_{12-41}$; HPA, hypothalamic-pituitary-adrenal; IBS, irritable bowel syndrome; LC, locus coeruleus; PVN, paraventricular nucleus of the hypothalamus.

Conflict of interest: The authors have declared that no conflict of interest exists. Citation for this article: J. Clin. Invest. 117:33-40 (2007). doi:10.1172/JCI30085. in the etiology of irritable bowel syndrome (IBS), which is characterized by altered bowel movements, bloating, and visceral pain (10-13). Cyclic vomiting syndrome is another brain-gut disorder manifested by recurrent, stereotyped episodes of nausea and vomiting in the pediatric population, which is triggered by stressors related to heightened emotional state, fasting, exercise, and infection in $80 \%$ of the patients (14).

A big step forward in our understanding of the neurocircuits and biochemical effectors that coordinate the physiological response to stress came from the identification in the hypothalamus of the 41-aa peptide corticotropin-releasing factor (CRF) by Vale et al. in 1981 (15). Since then, experimental studies in nonprimates and primates have supported the notion that CRF signaling is a key component of the multifaceted acute response to stress and that overactivity of this pathway has a role in the pathophysiology of various neuroendocrine and psychiatric illnesses related to stress, including anxiety and depression (16-18). Consequently, emphasis has been placed on elucidating the level of involvement of CRF signaling pathways, in both the brain and the gut, in the alterations of gut motor function known to be associated with stress $(5,19)$. In addition, the clinical relevance of overactive CRF signaling in the brain and periphery in functional bowel diseases is receiving increasing interest $(20,21)$, particularly because of the high prevalence of coexisting psychiatric disorders, prominently anxiety and depression, in IBS patients (22).

In this Review, we first discuss recent advances in our knowledge of CRF signaling as it relates to CRF family members and their receptors, as well as the insight provided by the development of CRF receptor antagonists. Preclinical studies supporting a primary role for CRF receptor activation in the brain and gut in mediating the alterations of gastric and colonic motor function associated with exposure to various stressors are outlined. The potential relevance of CRF signaling pathways in the pathogenesis and treatment of IBS is also addressed $(20,23)$.

\section{CRF signaling pathways}

CRF family members and receptors. CRF was the first peptide isolated (15) of a family of mammalian CRF-related peptides that now includes urocortin 1, urocortin 2 (also known as stresscopin-related peptide), and urocortin 3 (also known as stresscopin) 


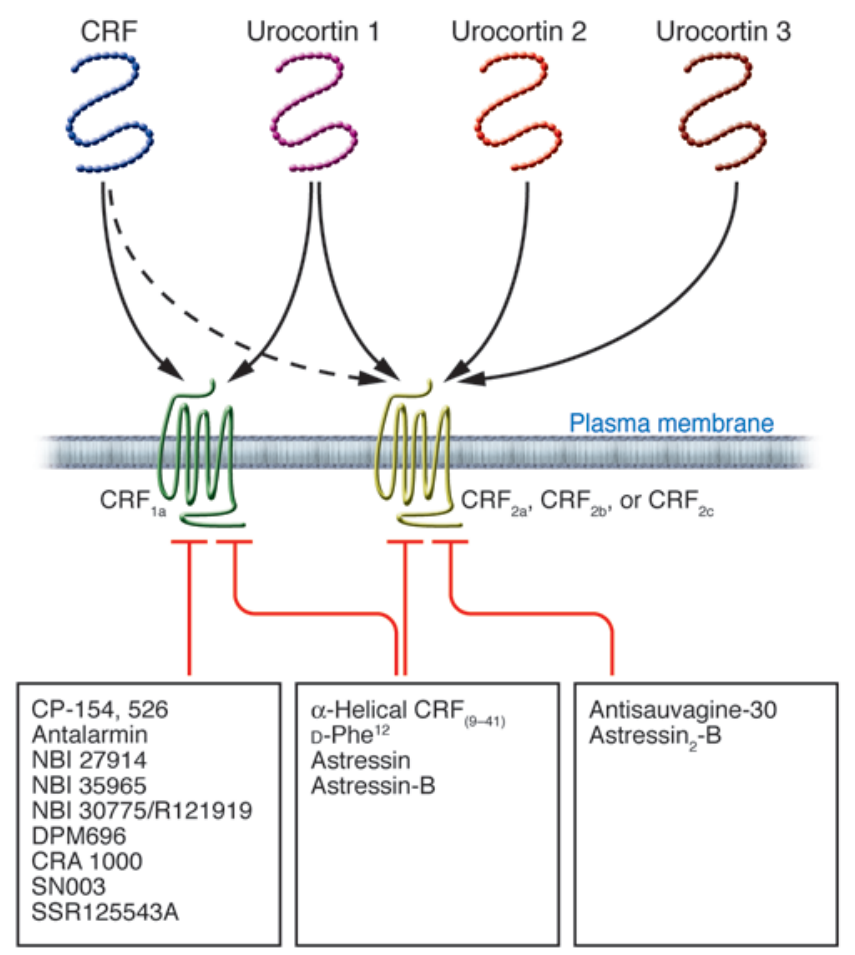

Figure 1

Overview of the family of peptides related to CRF and their receptors and receptor antagonists. CRF was the first peptide isolated of a family of mammalian CRF-related peptides that now includes urocortin 1, urocortin 2, and urocortin 3. CRF can bind either of $2 \mathrm{CRF}$ receptors, CRF receptor type $1\left(\mathrm{CRF}_{1}\right)$ or $\mathrm{CRF}$ receptor type $2\left(\mathrm{CRF}_{2}\right)$, although it has a preferential affinity for $\mathrm{CRF}_{1}$. By contrast, urocortin 1 has equal affinity for both receptors, and urocortin 2 and urocortin 3 are selective ligands for $\mathrm{CRF}_{2}$ receptors. Both CRF receptors share $70 \%$ similarity and belong to the 7-transmembrane-G protein-coupled superfamily. $\mathrm{CRF}_{1}$-selective antagonists are small nonpeptide molecules, while nonselective and $\mathrm{CRF}_{2}$ antagonists are peptides.

(24) (Figure 1). Consistent with a role for this family of peptides in survival and adaptation, the structures of CRF and urocortin 1 are highly conserved across mammalian species and during evolution, as shown by the $45 \%-48 \%$ similarity with the nonmammalian CRF-related peptides sauvagine (which has been isolated from the amphibian Phyllomedusa sauvagii) and urotensin I (which has been isolated from fish) (25).

CRF and the urocortins exert their biological actions on target cells through activation of 2 receptors, known as CRF receptor type $1\left(\mathrm{CRF}_{1}\right)$ and $\mathrm{CRF}$ receptor type $2\left(\mathrm{CRF}_{2}\right)$, which are encoded by 2 distinct genes (26). CRF 1 and $\mathrm{CRF}_{2}$ belong to the $\mathrm{B} 1$ class subfamily of 7 -transmembrane-domain $\mathrm{G}$ protein-coupled receptors $(26,27)$ (Figure 1 ). $\mathrm{CRF}_{1 \mathrm{a}}$ is the main functional variant of $\mathrm{CRF}_{1}$ and is widely expressed in the brain and some peripheral tissues in mammals (26). In addition, alternative splicing of the primary transcript encoding $\mathrm{CRF}_{1}$ can lead to a number of other variants, named $\mathrm{CRF}_{1 \mathrm{~b}-\mathrm{n}}$, all of which display impaired signaling (26). The expression of the $\mathrm{CRF}_{1 \mathrm{~b}-\mathrm{n}}$ variants is tissue specific, can vary with the functional activity of the tissues, and might be influenced by environmental factors - as reported so far in the skin of humans and rodents and in human myometrium and placenta (26). The functional significance of these other tran- scripts is still poorly characterized, but some splice variants, such as $\mathrm{CRF}_{1 \mathrm{~d}}$, have been reported to modulate CRF and urocortin 1 signaling in transfected cells by acting as a "decoy receptor" able to compete with $\mathrm{CRF}_{1 \mathrm{a}}$ for agonist binding (26). In addition, recent data in human myometrial smooth muscle cells indicate that steroids can change the ratio of expression of $\mathrm{CRF}_{1 \mathrm{a}}$ and $\mathrm{CRF}_{1 \mathrm{~b}}$, with increased expression of the $\mathrm{CRF}_{1 \mathrm{a}}$ functional form of $\mathrm{CRF}_{1}$ and decreased expression of the nonfunctional form $\mathrm{CRF}_{1 \mathrm{~b}}$, thereby enhancing tissue responsiveness to CRF (26). However, similar information regarding the expression of various $\mathrm{CRF}_{1}$ splice variants in the brain and gut, and their regulation in these tissues under stress conditions, is still lacking.

In contrast to $\mathrm{CRF}_{1}, 3$ functional $\mathrm{CRF}_{2}$ variants, $2 \alpha, 2 \beta$, and $2 \gamma$ (renamed 2a, 2b, and 2c), have been identified in mammals $(24,26)$. The $\mathrm{CRF}_{2}$ variants have a common carboxy-terminal region and structurally distinct amino-terminal extracellular domains (the region involved in ligand binding) that contain 34 aas for $\mathrm{CRF}_{2 \mathrm{a}}, 61$ aas for $\mathrm{CRF}_{2 \mathrm{~b}}$, and 20 aas for $\mathrm{CRF}_{2 \mathrm{c}}(24,28)$. Recently, a novel soluble splice variant has been identified in the mouse brain and shown to encode only the first extracellular domain of $\mathrm{CRF}_{2 \mathrm{a}}$ and to function as a soluble binding protein for CRF and urocortin 1 (29).

Despite sharing $70 \%$ aa sequence similarity, $\mathrm{CRF}_{1}$ and $\mathrm{CRF}_{2}$ display distinct characteristic affinities for the CRF family of peptides (Figure 1) (24, 26). CRF has a higher affinity (10- to 40-fold higher) for $\mathrm{CRF}_{1}$ than for $\mathrm{CRF}_{2}$, whereas all the urocortins signal preferentially through $\mathrm{CRF}_{2}$. Urocortin 1 binds $\mathrm{CRF}_{2}$ with 100 -fold greater affinity than does $\mathrm{CRF}$, and $\mathrm{CRF}_{1}$ with 6 -fold greater affinity than does CRF (30-32). Urocortin 2 and urocortin 3 exhibit high selectivity only for $\mathrm{CRF}_{2}(31,32)$, with a slightly higher affinity for $\mathrm{CRF}_{2 b}$ compared with $\mathrm{CRF}_{2 a}$, and a low affinity for the new soluble $\mathrm{CRF}_{2 a}$ splice variant $(29,32)$ (Figure 1$). \mathrm{CRF}_{2}$ variants display tissue- and species-specific expression. In nonprimate mammals, $\mathrm{CRF}_{2 \mathrm{a}}$ is expressed only by neurons and $\mathrm{CRF}_{2 \mathrm{~b}}$ mainly in the periphery and by non-neuronal cells of the brain (33), whereas $\mathrm{CRF}_{2 c}$ is found only in the amygdala of the human brain (34). It is well documented that stimulation of $\mathrm{CRF}_{1 \mathrm{a}}, \mathrm{CRF}_{2 \mathrm{a}}$, and $\mathrm{CRF}_{2 \mathrm{~b}}$ activates adenylyl cyclase/ cAMP signaling pathways through coupling and activation of $G \alpha_{s}$ proteins (26). However, several recent reports indicate that the nature of a trimeric complex, made of CRF agonist, CRF receptor, and $G$ protein, influences the pattern of intracellular signaling in a tissue-specific manner (26).

$C R F$ receptor antagonists. The development of competitive CRF receptor antagonists was an important early development in the endeavor to determine the functions of CRF receptors under basal and stress conditions (35). The first CRF antagonist was $\alpha$-helical $\mathrm{CRF}_{9-41}$, a CRF analog generated by deletion of 8 aas from the amidated carboxyl terminus of CRF $(27,36)$. A subsequent approach to enhance the potency of CRF antagonists was to design analogs in which the secondary structure of CRF was constrained, leading to the generation of $\left[\mathrm{D}-\mathrm{Phe}^{12}, \mathrm{Nle}^{21,38}, \mathrm{C} \alpha \mathrm{MeLeu}^{37}\right] \mathrm{CRF}_{12-41}$ $\left(\mathrm{D}-\mathrm{Phe}^{12} \mathrm{CRF}_{12-41}\right)$ and cyclo(30-33) $\left[\mathrm{D}-\mathrm{Phe}^{12}, \mathrm{Nle}^{21,38}, \mathrm{Glu}^{30}, \mathrm{Lys}^{33}\right] \mathrm{Ac}-$ $\mathrm{CRF}_{9-41}$ (known as astressin) (37). Additional astressin-like analogs were later developed, of which cyclo(30-33)[D-Phe ${ }^{12}, \mathrm{Nle}^{21}$, $\mathrm{C} \mathrm{MeLeu}{ }^{27}, \mathrm{Glu}^{30}, \mathrm{Lys}^{33}, \mathrm{Nle}^{38}, \mathrm{C}^{3 \mathrm{MeLeu}}{ }^{40} \mathrm{Ac}^{-\mathrm{CRF}_{9-41}}$ (known as astressin-B) is the most efficacious and long-acting (being still effective 24 hours after a single peripheral injection) (38). The use of these CRF antagonists has unraveled the many roles that CRF receptors have in orchestrating the behavioral (anxiety, decreased feeding, and drug seeking), cognitive (arousal and anxiety), neuroendocrine (ACTH and $\beta$-endorphin release), autonomic (activation of the sym- 
pathetic nervous system), immunological, and visceral (hypertension and alterations in gut motor function) responses to stress.

However, these CRF antagonists bind both $\mathrm{CRF}_{1}$ and $\mathrm{CRF}_{2}$ and, therefore, do not provide selectivity to assess the involvement of the 2 CRF receptor subtypes $(27,42)$ (Figure 1). An important goal was reached recently when competitive and selective peptide antagonists for $\mathrm{CRF}_{2}$ were developed and shown to bind equally to the $a, b$, and $c$ variants of $\mathrm{CRF}_{2}$ while having little to no affinity for $\mathrm{CRF}_{1}$ receptors $(29,43,44)$ (Figure 1 ). Three of these peptides are $\left[\mathrm{D}-\mathrm{Phe}^{11}, \mathrm{His}^{12}\right]$ sauvagine ${ }_{11-40}$ (known as antisauvagine- 30 ), $\left[\mathrm{D}-\mathrm{Phe}^{11}{ }^{1} \mathrm{His}^{12}{ }^{12} \mathrm{Nle}^{17}\right]$ sauvagine ${ }_{11-40}$ (known as K41498), and the long-acting analog with additional conformational constraints, cyclo(31-34)[D-Phe $\left.{ }^{11}, \mathrm{His}^{12}, \mathrm{Nle}^{12}, \mathrm{C} \alpha M e \mathrm{Leu}^{13,39}, \mathrm{Nle}^{17}, \mathrm{Glu}^{31}, \mathrm{Lys}^{34}\right]$ Ac-sauvagine $_{8-40}$ (known as astressin $2-B$ ) (Figure 1). So far, there are no peptide analogs that are selective $\mathrm{CRF}_{1}$ antagonists; however, a flurry of patents for orally bioavailable, nonpeptidic selective $\mathrm{CRF}_{1}$ antagonists have been recently disclosed $(16,35)$. These small-molecular weight compounds cross the blood-brain barrier with a penetrance largely influenced by their distinct physicochemical properties, particularly their lipophilicity (35). Among the selective $\mathrm{CRF}_{1}$ antagonists, CP-154,526, antalarmin, DPM696, NBI 30775 (also known as R121919), and NBI 35965 have been among the most commonly used and characterized $(35,45,46)$ (Figure 1). With the availability of selective CRF receptor antagonists, it has become clear that the constellation of physiological effects produced by endogenous CRF peptides might be attributed to actions on distinct CRF receptor subtypes. Compelling evidence indicates that activation of the brain CRF-CRF $F_{1}$ signaling pathway has a leading role in coordinating many of the physiological responses to adaptive stress as it relates to the activation of the hypothalamic-pituitary-adrenal (HPA) axis, sympathetic nervous system, and changes in cardiovascular, colonic, and immune functions in rodents and primates (23, 39, 47-49). Preclinical and clinical studies also indicate that abnormally increased central $\mathrm{CRF}_{1}$ signaling contributes to the pathogenesis of anxiety and depression and can have implications in the pathophysiology of IBS $(18,20,49)$. With regard to $\mathrm{CRF}_{2}$ receptors in the brain, emerging evidence supports a role for these receptors as mediators of ways to dampen and/or facilitate the proper recovery of the $\mathrm{CRF}_{1}$-initiated behavioral, endocrine, and visceral responses to stress (50-52). However, in some systems - for instance, the suppression of feeding behavior - activation of $\mathrm{CRF}_{2}$ has an additive effect with the $\mathrm{CRF}_{1}$-mediated orexigenic effect (49).

\section{Link between CRF receptors in the brain and stress- related alterations of gut motor function}

Convergent experimental reports have shown that central injection of CRF and urocortins reproduces stress-related alterations of gut motor function in naive rodents, whereas central injection of CRF antagonists prevents the effects of various stressors, supporting a crucial role for CRF receptors in the brain in the regulation of stress-induced alterations in gastrointestinal motility (53).

Stress, CRF receptors in the brain, and gastric transit. CRF, urocortin 1 , urocortin 2, and the nonmammalian CRF-related peptides sauvagine and urotensin I inhibit gastric emptying of noncaloric liquid, caloric liquid, and solid food when injected into the cerebrospinal fluid (CSF) of several nonprimate mammals (53). These peptides also inhibit basal and cholinergic-stimulated gastric motility in rodents and dogs $(54,55) . \mathrm{CRF}_{2}$ is the CRF receptor subtype in the brain through which CRF and urocortins injected into the CSF pri- marily initiate their inhibitory effect on gastric transit and motility (56-58). Sites of CRF action in the brain are specific and localized in the paraventricular nucleus of the hypothalamus (PVN) and the dorsal vagal complex nuclei, both of which contain neurons bearing $\mathrm{CRF}_{2 \mathrm{a}}$ and are known to influence autonomic nervous outflow to the stomach (Figure 2) $(53,59,60)$. Consistent with this, blocking of the transmission of impulses by the autonomic nervous system prevents CRF injected into the CSF or PVN from inhibiting gastric transit (61-62). Removal of the pituitary gland or adrenal glands had no effect on CRF inhibition of gastric emptying; this indicates that the gastric effect is not secondary to the activation of the HPA axis $(61,62)$. All reports, except $2(61,63)$, have identified the vagus nerve as the main pathway mediating the delayed gastric transit and inhibition of gastric motility induced by central injection of either CRF or urocortin 1 in rats and dogs (54, $55,57,59,62,64,65)$. By contrast, the delayed gastric emptying induced by injection of urocortin 2 into the CSF is not altered by gastric vagotomy and instead requires the integrity of the sympathetic nervous system and peripheral $\alpha$-adrenergic receptors (57). These data indicate that CRF and its related peptides differentially modulate vagal and sympathetic components of the autonomic nervous system to suppress gastric motor function.

The importance of CRF signaling in the brain was established using pharmacological blockade of CRF receptors. Injection of $\alpha$-helical $\mathrm{CRF}_{9-41}, \mathrm{D}-\mathrm{Phe}^{12} \mathrm{CRF}_{12-41}$, astressin, or astressin-B into the CSF or PVN completely prevented the delayed gastric emptying induced by various psychological, physical, visceral, immunological, or chemical stressors, including swim stress, restraint, abdominal or cranial surgery, peritoneal irritation with $0.6 \%$ acetic acid, systemic or brain injection of IL-1 $\beta$, and exposure to ether anesthesia $(5,63,66)$. Consistent with this, various stressors, including abdominal surgery and peripheral administration of IL- $1 \beta$, activate neurons that express CRF and upregulate levels of mRNA encoding CRF in the PVN (67-70). Likewise, urocortin 1, urocortin 2, and urocortin 3 are present in the PVN, and expression of the urocortins is upregulated during stress $(49,71,72)$. The CRF receptor subtypes and endogenous CRF ligands primarily involved in delaying gastric motor function under stress conditions have been characterized in only a few studies so far. The $\mathrm{CRF}_{2}$ antagonist astressin 2 -B injected into the CSF abolished the delayed gastric emptying in response to restraint in rats (63). By contrast, pharmacological blockade with a selective $\mathrm{CRF}_{1}$ antagonist and the use of mice lacking $\mathrm{CRF}_{1}$ suppressed the inhibition of gastric transit induced by surgical stress (caused by abdominal surgery or cecal palpation) (73). Collectively, these data provide new insights into the role of specific CRF receptors in the brain in the altered gastric digestive function that occurs in response to stress of surgical or immunological origin. As inhibition of gastric propulsive activity after surgical intervention represents a substantial medical problem for which effective treatments are still lacking (74), these experimental findings might open new therapeutic avenues.

Stress, CRF receptors in the brain, and small-intestinal transit. Alterations in small-intestinal motor function induced by stress and CRF ligands have been investigated in parallel with those occurring in the stomach (53). Acute psychological stress and central injection of CRF and urocortin 1 exert an inhibitory effect on duodenal and small-intestinal transit and propulsive motility, similar to their effects on gastric functions $(6,54,65,66,75-77)$. Peptide-inhibitory action is mediated directly by vagal nerves and is independent of activation of the HPA axis $(6,61,66,78)$. 


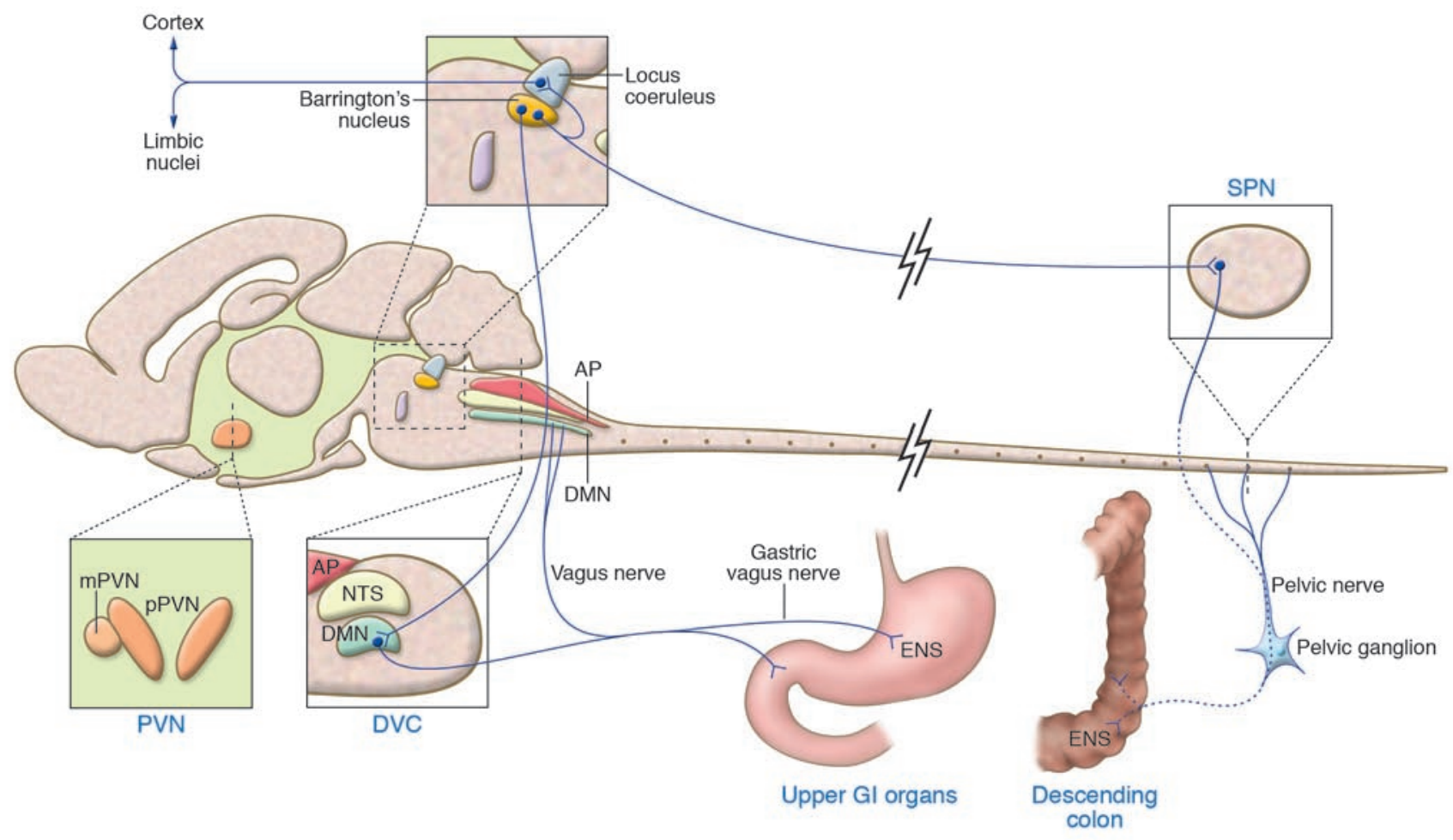

Figure 2

Lengthwise drawing of the rat brain showing the regions in which the activation of receptors for CRF influences gastric and colonic motor function through neural pathways innervating the gut. The Barrington's nucleus, through its reciprocal connections with the LC, can be influenced by or influence the noradrenergic-containing neurons in the LC that project to the forebrain. Efferent fibers from the Barrington's complex also project to neurons in the dorsal motor nucleus (DMN) and the sacral parasympathetic nucleus (SPN). Axons from DMN neurons provide vagal innervation to the stomach. The end target of vagal efferent fibers is the enteric nervous system (ENS) in the stomach wall. Stress activates the PVN, LC, and Barrington's nucleus, resulting in autonomic nervous system-mediated inhibition of gastric and stimulation of colonic transit and motility. Vertical lines indicate coronal sections at the PVN and dorsal vagal complex (DVC). AP, area postrema; GI, gastrointestinal; mPVN, magnocellular PVN; NTS, nucleus tractus solitarius; pPVN, parvocellular PVN. Adapted with permission from Trends in Pharmacological Sciences (ref. 91; Figure 1).

The inhibitory action of central CRF on small-intestinal transit is, however, less prominent than its inhibitory action on gastric transit; this most probably reflects the lesser density of vagal innervation of the small intestine as compared with the stomach (79). In addition, the role of CRF receptors in the brain in stressrelated inhibition of small-intestinal transit is yet to be characterized. The reduction of small-intestinal transit induced by partial restraint was reported to be blocked in male, but not in female, rats injected with $\alpha$-helical $\mathrm{CRF}_{9-41}$ into the $\operatorname{CSF}(6,66)$. Whether these conflicting data relate to sex differences or other experimental components remains to be determined.

Stress, $C R F_{1}$ in the brain, and colonic transit. In contrast to the inhibitory effects of CRF and urocortin 1 injected into the CSF on gastric and small-intestinal motor function, these peptides stimulate colonic transit and defecation and induce diarrhea through increased sacral parasympathetic outflow to the large intestine in female and male rats, mice, and gerbils $(6,7,56,61,80-85)$. Convergent studies have shown that the activation of $\mathrm{CRF}_{1}$ receptors in the brain contributes to the stimulatory effects of central injection of CRF and urocortin 1, as well as the stimulatory effects of various stressors, on colonic motor function $(23,53)$. First, the colonic propulsive motor activity induced by stress is mimicked by central administration of urocortin 1 and the preferential $\mathrm{CRF}_{1}$ agonist ovine $\mathrm{CRF}$ (27), whereas the selective $\mathrm{CRF}_{2}$ agonists urocortin 2 and urocortin 3, injected into the CSF at a dose similar to that of CRF, are inactive (56). In addition, central administration of the pan-CRF peptide antagonists $\alpha$-helical $\mathrm{CRF}_{9-41}$, D-Phe ${ }^{12} \mathrm{CRF}_{12-41}$, and astressin blocked the colonic motor stimulation (motility, transit, and defecation) induced by central injection of CRF and urocortin 1, as well as by various stressors (wrap or partial restraint, water avoidance, conditioned fear, IL-1 $\beta$ injected into the CSF, and morphine withdrawal) (6, 7, $56,66,80,82,83,86-89)$. Similarly, the selective $\mathrm{CRF}_{1}$ antagonists CP-154,526, CRA 1000, NBI 27914, NBI 35965, and antalarmin, injected either into the CSF or i.p., prevented the acceleration of colonic transit induced by restraint, dampened defecation in response to water avoidance, restraint, and social stress, and inhibited the diarrhea elicited by morphine withdrawal (23). Likewise, $\mathrm{CRF}_{1}$-deficient mice have lower defecation scores than wild-type littermates in an open-field test (90). Lastly, the $\mathrm{CRF}_{2}$-specific peptide antagonist astressin $\sin _{2} \mathrm{~B}$, injected into the CSF at doses that block $\mathrm{CRF}_{2}$ effects on gastric emptying, did not inhibit the stimulatory effect of CRF on colon function in rodents $(5,23,56)$.

The PVN, the locus coeruleus (LC), and the Barrington's nucleus, which lies just ventromedial to the $\mathrm{LC}$, are areas of the brain where CRF and stress stimulate colonic motor function and anxious behavior $(16,91)$ (Figure 2). These sites are activated by water- 
avoidance stress, as is shown by their increased expression of FOS, a neuronal marker of cell activation (80). Water avoidance also induces rapid transcription of the gene encoding CRF in the PVN (92). Furthermore, $\alpha$-helical $\mathrm{CRF}_{9-41}$ injected into the PVN prevents the stimulation of colonic transit and defecation induced by partial restraint and water avoidance $(64,80,87)$. Likewise, in inbred rats with a genetically impaired hypothalamic CRF response to stress (93), water avoidance results in a reduced activation of neurons in the PVN and sacral parasympathetic nucleus (as shown by decreased expression of FOS) and is associated with an attenuated colonic motor response (86). Moreover, expression of the gene encoding $\mathrm{CRF}_{1}$ in the PVN (60) is markedly increased by different types of interoceptive or exteroceptive stressors (94). It has been shown that CRF-synthesizing neurons in the Barrington's nucleus project to both the noradrenergic LC and the sacral parasympathetic nucleus of the spinal cord, which innervates the descending colon (Figure 2) $(91,95)$. In the LC, CRF increases the rate at which noradrenergic neurons fire and thereby increases the amount of noradrenalin released into the brain cortex, leading to arousal and anxiogenic behavior (Figure 2) $(91,96)$. Consequently, the activation of CRF$\mathrm{CRF}_{1}$ signaling in the PVN and $\operatorname{LC}(94,97)$ is well positioned to participate in stress circuits that coordinate behavioral anxiogenic and autonomic responses that impact colonic motility $(81,91)$. It might be speculated that overactivity of these neurological circuits has relevance to the high incidence of anxiety disorders in patients with IBS and that these effects might be efficiently targeted by $\mathrm{CRF}_{1}$ antagonists $(16,23,98)$.

\section{Peripheral CRF signaling and stress-related alterations of gut motor function}

As established for a number of neuropeptides (such as somatostatin, opiates, and calcitonin gene-related peptides) that act in the brain to influence gut motility (99), the CRF ligands and receptors that were initially characterized in the brain (where they function to influence gut motor function) have recently been shown to be widely expressed in peripheral tissues, including the gastrointestinal tract of experimental animals and humans $(19,32,100-103)$. The coincident expression of CRF ligands, mostly urocortins, with cognate receptors provided strong support for the idea that their local action could influence gut motor function (100-102, 104, 105).

$C R F$ receptors in the periphery and gut transit. Initial functional studies showed that injection of CRF peripherally alters gut motility and transit in several mammalian species, including rodents, dogs, and humans $(6,62,106-109)$. In particular, injection of CRF either i.v. or i.p. inhibited gastric emptying, delayed small-intestinal transit, stimulated colonic transit and defecation, and induced diarrhea with a potency similar to that of CRF injected into the CSF (6, $61,106)$. Although central administration and peripheral administration of CRF result in similar gut transit alterations, distinct sites and mechanisms of action are involved $(54,57,61,110,111)$. For example, pharmacological blockade of autonomic outflow does not modify the inhibition of gastric emptying and acceleration of colonic transit induced by injection of CRF i.p., whereas it abrogates the gastric and colonic responses induced by injection of CRF into the CSF (61). In addition, injection of $\alpha$-helical $\mathrm{CRF}_{9-41}$ into the CSF does not modify the stimulation of colonic transit induced by injection of CRF i.v.; this indicates that the peripherally injected CRF did not activate CRF receptors in the brain (66).

Further studies in rodents have established that peripheral injection of CRF, urocortin 1, urocortin 2, or urocortin 3 delays gastric emptying by activating $\mathrm{CRF}_{2}$, whereas peripheral injection of CRF or urocortin 1 stimulates colonic motility through activation of $\mathrm{CRF}_{1}$ expressed by colonic myenteric neurons (19). This was shown by the fact that injection of the selective $\mathrm{CRF}_{2}$ agonists, urocortin 2, or, less potently, urocortin 3 either i.p. or i.v. inhibited gastric emptying of a solid or liquid meal but did not influence distal colonic transit in rodents $(106,112)$. By contrast, under the same conditions, CRF and urocortin 1 inhibited gastric motor function and stimulated colonic propulsion and defecation in rats and mice $(54,106,112)$. Moreover, in rodents, peripheral injection of the $\mathrm{CRF}_{2}$-specific antagonists astressin ${ }_{2}-\mathrm{B}$ and antisauvagine- 30 prevented the inhibition of gastric emptying that is induced by CRF and urocortin 1 given i.v. or i.p. but did not modify their stimulation of distal colonic transit $(106,112)$. Conversely, peripheral injection of the $\mathrm{CRF}_{1}$-specific antagonists CP-154,526 and NBI 27914 blocked the stimulation of colonic transit, defecation, and diarrhea induced by i.p. injection of CRF and urocortin 1 but did not prevent delayed gastric emptying $(106,112-114)$. The mechanisms by which peripherally administered CRF and urocortin 1 stimulate colonic motor activity might involve direct activation of colonic myenteric neurons that lie between the longitudinal and circular muscles. Indeed, in rats, high levels of FOS expression are induced in neurons of the colonic myenteric ganglia by CRF injected i.p., and this is blocked by peripheral injection of astressin and CP-154,526 (115). These data are consistent with the expression of $\mathrm{CRF}_{1}$ by rat colonic myenteric neurons $(101,104)$.

CRF receptors in the periphery and gut motility. Analysis of the motility changes underlying gut transit alterations showed that i.v. injection of urocortin 1 or CRF reduces the amplitude of postprandial gastric contractions, inhibits jejunal motility induced by i.v. injection of motilin, and increases propulsive colonic motility in experimental animals $(54,113,116,117)$. The motor alterations induced by CRF and urocortin 1 were reproduced in vitro in isolated stomach tissue and distal segments of the colon, which both have functional enteric neurons; this supports the idea of local peripheral action $(102,105,113,118,119)$. Studies in healthy humans revealed that i.v. injection of CRF increases nonpropulsive postprandial duodenal motor activity and stimulates propulsive motor contractions in the descending colon $(108,109)$. Of interest is the report that patients with IBS show enhanced colonic motility in response to i.v. injection of CRF as compared with healthy volunteers, which indicates that they are hyperresponsive to CRF, and this might be linked by upregulation of colonic $\mathrm{CRF}_{1}$ (108).

Stress, CRF receptors in the periphery, and gut transit. Pharmacological studies support the notion that gut CRF signaling occurs under stress $(6,19,112,113)$. Several reports showed that the delayed gastric emptying induced by abdominal surgery can be blocked by peripheral injection of $\alpha$-helical $\mathrm{CRF}_{9-41}, \mathrm{D}-\mathrm{Phe}^{12} \mathrm{CRF}_{12-41}$, and astressin $(111,120,121) . \mathrm{CRF}_{2}$ antagonists injected i.v. also prevented the inhibition of gastric emptying induced by acute wraprestraint stress, whereas the selective $\mathrm{CRF}_{1}$ antagonist CP-154,526 did not (112). With respect to stress-related stimulation of colonic motor function, peripheral administration of $\alpha$-helical $\mathrm{CRF}_{9-41}$, astressin, and CP-154,526, but not of astressin $\sin _{2}-\mathrm{B}$, prevented or blunted the stimulation of distal colonic transit and defecation induced by acute wrap-restraint and water-avoidance stress $(6,83$, $112,113,122)$. In patients with IBS, compared with healthy subjects, the administration of $\alpha$-helical $\mathrm{CRF}_{9-41}$ improves colonic motility, visceral perception, and the negative mood elicited by rectal transmural electrical stimulation, without affecting the HPA axis (20). 
The cellular origins of the CRF and CRF-related peptides that activate peripheral CRF receptors present in the gut remain to be elucidated. CRF ligands have been detected in the gut myenteric nervous system, as well as in enteroendocrine cells and lamina propria macrophages in rodents and humans $(103,123,124)$. Because both central and peripheral administration of CRF receptor antagonists is able to counteract the impact of stress on gut motility, this supports the concept that stress influences the release of CRF ligands in the gut through autonomic pathways, where they can then function as local effectors of altered gastrointestinal motility.

\section{Conclusions and future perspectives}

CRF signaling in the brain, established as a leading mediator of the biochemical effect on the endocrine and anxiogenic behavioral responses to stress, is also part of the underlying mechanisms through which stress inhibits gastric transit and stimulates colonic transit in experimental animals. In addition to the brain, the gut is endowed with a CRF-signaling system that also has a role as a local effector of the autonomic nervous system-mediated gastrointestinal response to stress. Of clinical relevance are experimental studies showing that activation of $\mathrm{CRF}_{1}$ pathways recaptures the key features of symptoms in IBS diarrhea-predominant patients, such as stimulation of colonic motility, defecation/watery diarrhea, visceral hypersensitivity, and anxiogenic/hypervigilant behavior, that are alleviated by $\mathrm{CRF}_{1}$ receptor antagonists (23). These data support the involvement of the $\mathrm{CRF}_{1}$ system at central and/or peripheral sites as part of the mechanisms whereby stress triggers or enhances gut complaints in patients with IBS (9-11). The promising completion of the first open-label clinical trial with the $\mathrm{CRF}_{1}$ antagonist R121919 in severely depressed patients (125), along with the improvement of colonic motility and visceral perception by peripheral injection of the CRF antagonist $\alpha$-helical $\mathrm{CRF}_{9-41}$ in IBS diarrhea-predominant patients (20), provides a strong basis for therapeutic use of $\mathrm{CRF}_{1}$ antagonists to treat IBS, particularly given the high frequency of comorbid psychiatric disorders in IBS (22).

\section{Acknowledgments}

The authors' work was supported by the National Institute of Diabetes, Digestive and Kidney Diseases (grants R01 DK33061, R01 DK57236, DK41301 [Animal Core], and P50 AR049550) and by Veterans Affairs Merit and Senior Scientist Awards. The help of Teresa Olivas in preparing the manuscript is gratefully acknowledged.

Address correspondence to: Yvette Taché, Center for Neurovisceral Sciences, Building 115, Room 117, VA Greater Los Angeles Healthcare System, 11301 Wilshire Boulevard, Los Angeles, California 90073, USA. Phone: (310) 312-9275; Fax: (310) 268-4963; E-mail: ytache@mednet.ucla.edu.
1. Chrousos, G.P. 2000. The role of stress and the hypothalamic-pituitary-adrenal axis in the pathogenesis of the metabolic syndrome: neuro-endocrine and target tissue-related causes. Int. J. Obes. Relat. Metab. Disord. 24(Suppl. 2):S50-S55.

2. Enck, P., and Holtmann, G. 1992. Stress and gastrointestinal motility in animals: a review of the literature. Journal of Gastrointestinal Motility. 1:83-90.

3. Cannon, W.B. 1953. Bodily changes in pain, hunger, fear and rage. Charles T. Branford. Boston, Massachusetts, USA. 1-404.

4. Almy, T.P., Hinkle, L.E., Berle, B., and Kern, F., Jr. 1949. Alterations in colonic function in man under stress. Experimental production of sigmoid spasm in patients with spastic constipation. Gastroenterology. 12:437-449.

5. Taché, Y., Martinez, V., Million, M., and Wang, L. 2001. Stress and the gastrointestinal tract. III. Stressrelated alterations of gut motor function: role of brain corticotropin-releasing factor receptors. Am. J. Physiol. Gastrointest. Liver Physiol. 280:G173-G177.

6. Williams, C.L., Peterson, J.M., Villar, R.G., and Burks, T.F. 1987. Corticotropin-releasing factor directly mediates colonic responses to stress. $\mathrm{Am}$. J. Physiol. 253:G582-G586.

7. Gué, M., Junien, J.L., and Buéno, L. 1991. Conditioned emotional response in rats enhances colonic motility through the central release of corticotropin-releasing factor. Gastroenterology. 100:964-970.

8. Grundy, D., et al. 2006. Fundamentals of neurogastroenterology: basic science. Gastroenterology. 130:1391-1411.

9. Gwee, K.A., et al. 1999. The role of psychological and biological factors in postinfective gut dysfunction. Gut. 44:400-406.

10. Halpert, A., and Drossman, D. 2005. Biopsychosocial issues in irritable bowel syndrome. J. Clin. Gastroenterol. 39:665-669.

11. Mayer, E.A., Naliboff, B.D., Chang, L., and Coutinho, S.V. 2001. Stress and the gastrointestinal tract. V. Stress and irritable bowel syndrome. Am. J. Physiol. Gastrointest. Liver Physiol. 280:G519-G524.

12. Mönnikes, H., et al. 2001. Role of stress in functional gastrointestinal disorders. Evidence for stress-induced alterations in gastrointestinal motility and sensitivity. Dig. Dis. 19:201-211.
13. Mulak, A., and Bonaz, B. 2004. Irritable bowel syndrome: a model of the brain-gut interactions. Med. Sci. Monit. 10:RA52-RA62.

14. Li, B.U., and Misiewicz, L. 2003. Cyclic vomiting syndrome: a brain-gut disorder. Gastroenterol. Clin. North Am. 32:997-1019.

15. Vale, W., Spiess, J., Rivier, C., and Rivier, J. 1981. Characterization of a 41-residue ovine hypothalamic peptide that stimulates secretion of corticotropin and $\beta$-endorphin. Science. 213:1394-1397.

16. Zorrilla, E.P., and Koob, G.F. 2004. The therapeutic potential of CRF1 antagonists for anxiety. Expert Opin. Investig. Drugs. 13:799-828.

17. Steckler, T., and Dautzenberg, F.M. 2006. Corticotropin-releasing factor receptor antagonists in affective disorders and drug dependence: an update. CNS Neurol. Disord. Drug Targets. 5:147-165.

18. Bale, T.L. 2005. Sensitivity to stress: dysregulation of CRF pathways and disease development. Horm. Behav. 48:1-10.

19. Taché, Y., and Perdue, M.H. 2004. Role of peripheral CRF signaling pathways in stress-related alterations of gut motility and mucosal function. Neurogastroenterol. Motil. 16(Suppl. 1):1-6.

20. Sagami, Y., et al. 2004. Effect of a corticotropin releasing hormone receptor antagonist on colonic sensory and motor function in patients with irritable bowel syndrome. Gut. 53:958-964.

21. Saps, M., and Li, B.U. 2006. Chronic abdominal pain of functional origin in children. Pediatr. Ann. 35:249-256.

22. Folks, D.G. 2004. The interface of psychiatry and irritable bowel syndrome. Curr. Psychiatry Rep. 6:210-215.

23. Martinez, V., and Taché, Y. 2006. $\mathrm{CRF}_{1}$ receptors as a therapeutic target for irritable bowel syndrome. Curr. Pharm. Des. 12:4071-4088.

24. Hauger, R.L., et al. 2003. International Union of Pharmacology. XXXVI. Current status of the nomenclature for receptors for corticotropinreleasing factor and their ligands. Pharmacol. Rev. 55:21-26.

25. Lovejoy, D.A., and Balment, R.J. 1999. Evolution and physiology of the corticotropin-releasing factor (CRF) family of neuropeptides in vertebrates. Gen. Comp. Endocrinol. 115:1-22.
26. Hillhouse, E.W., and Grammatopoulos, D.K. 2006. The molecular mechanisms underlying the regulation of the biological activity of corticotropin-releasing hormone receptors: implications for physiology and pathophysiology. Endocr. Rev. 27:260-286.

27. Perrin, M.H., and Vale, W.W. 1999. Corticotropin releasing factor receptors and their ligand family. Ann. N. Y. Acad. Sci. 885:312-328.

28. Catalano, R.D., Kyriakou, T., Chen, J., Easton, A., and Hillhouse, E.W. 2003. Regulation of corticotropin-releasing hormone type 2 receptors by multiple promoters and alternative splicing: identification of multiple splice variants. Mol. Endocrinol. 17:395-410.

29. Chen, A.M., et al. 2005. A soluble mouse brain splice variant of type 2alpha corticotropin-releasing factor (CRF) receptor binds ligands and modulates their activity. Proc. Natl. Acad. Sci. U. S. A. 102:2620-2625.

30. Vaughan, J., et al. 1995. Urocortin, a mammalian neuropeptide related to fish urotensin I and to corticotropin-releasing factor. Nature. 378:287-292.

31. Reyes, T.M., et al. 2001. Urocortin II: a member of the corticotropin-releasing factor (CRF) neuropeptide family that is selectively bound by type $2 \mathrm{CRF}$ receptors. Proc. Natl. Acad. Sci. U. S. A. 98:2843-2848.

32. Lewis, K., et al. 2001. Identification of urocortin III, an additional member of the corticotropin-releasing factor (CRF) family with high affinity for the CRF2 receptor. Proc. Natl. Acad. Sci. U. S. A. 98:7570-7575.

33. Lovenberg, T.W., Chalmers, D.T., Liu, C., and De Souza, E.B. 1995. CRF $2 \alpha$ and CRF $2 \beta$ receptor mRNAs are differentially distributed between the rat central nervous system and peripheral tissues. Endocrinology. 136:4139-4142.

34. Kostich, W.A., Chen, A., Sperle, K., and Largent, B.L. 1998. Molecular identification and analysis of a novel human corticotropin-releasing factor (CRF) receptor: the CRF2 $\gamma$ receptor. Mol. Endocrinol. 12:1077-1085.

35. Chen, C. 2006. Recent advances in small molecule antagonists of the corticotropin-releasing factor type- 1 receptor-focus on pharmacology and pharmacokinetics. Curr. Med. Chem. 13:1261-1282.

36. Rivier, J., Rivier, C., and Vale, W. 1984. Synthetic 
competitive antagonists of corticotropin-releasing factor: effect on ACTH secretion in the rat. Science. 224:889-891

37. Gulyas, J., et al. 1995. Potent, structurally constrained agonists and competitive antagonists of corticotropin-releasing factor. Proc. Natl. Acad. Sci. U. S. A. 92:10575-10579.

38. Rivier, J.E., et al. 1999. Constrained corticotropin releasing factor antagonists (astressin analogues) with long duration of action in the rat. J. Med. Chem. 42:3175-3182.

39. Bale, T.L., and Vale, W.W. 2004. CRF and CRF receptor: role in stress responsivity and other behaviors. Annu. Rev. Pharmacol. Toxicol. 44:525-557.

40. Nazarloo, H.P., Buttrick, P.M., Saadat, H., and Dunn, A.J. 2006. The roles of corticotropin-releasing factor-related peptides and their receptors in the cardiovascular system. Curr. Protein Pept. Sci. 7:229-239.

41. Gravanis, A., and Margioris, A.N. 2005. The corticotropin-releasing factor (CRF) family of neuropeptides in inflammation: potential therapeutic applications. Curr. Med. Chem. 12:1503-1512.

42. Perrin, M.H., Sutton, S.W., Cervini, L.A., Rivier, J.E., and Vale, W.W. 1999. Comparison of an agonist, urocortin, and an antagonist, astressin, as radioligands for characterization of CRF receptors. J. Pharmacol. Exp. Ther. 288:729-734.

43. Ruhmann, A., Bonk, I., Lin, C.R., Rosenfeld, M.G., and Spiess, J. 1998. Structural requirements for peptidic antagonists of the corticotropin-releasing factor receptor (CRFR): development of CRFR2 $\beta$-selective antisauvagine-30. Proc. Natl. Acad. Sci. U. S. A. 95:15264-15269.

44. Rivier, J., et al. 2002. Potent and long-acting corticotropin releasing factor (CRF) receptor 2 selective peptide competitive antagonists. J. Med. Chem. 45:4737-4747.

45. Seymour, P.A., Schmidt, A.W., and Schulz, D.W. 2003. The pharmacology of CP-154,526, a nonpeptide antagonist of the CRH1 receptor: a review. CNS Drug Rev. 9:57-96.

46. Million, M., et al. 2003. A novel water-soluble selective $\mathrm{CRF}_{1}$ receptor antagonist, NBI 35965, blunts stress-induced visceral hyperalgesia and colonic motor function in rats. Brain Res. 985:32-42.

47. Habib, K.E., et al. 2000. Oral administration of a corticotropin-releasing hormone receptor antagonist significantly attenuates behavioral, neuroendocrine, and autonomic responses to stress in primates. Proc. Natl. Acad. Sci. U. S. A. 97:6079-6084.

48. Uetsuki, N., Segawa, H., Mayahara, T., and Fukuda, K. 2005. The role of $\mathrm{CRF}_{1}$ receptors for sympathetic nervous response to laparotomy in anesthetized rats. Brain Res. 1044:107-115.

49. Hauger, R.L., Risbrough, V., Brauns, O., and Dautzenberg, F.M. 2006. Corticotropin releasing factor $(\mathrm{CRF})$ receptor signaling in the central nervous system: new molecular targets. CNS Neurol. Disord. Drug Targets. 5:453-479.

50. Bale, T.L., et al. 2000. Mice deficient for corticotropin-releasing hormone receptor-2 display anxietylike behaviour and are hypersensitive to stress. Nat. Genet. 24:410-414.

51. Rivier, C.L., Grigoriadis, D.E., and Rivier, J.E. 2003. Role of corticotropin-releasing factor receptors type 1 and 2 in modulating the rat adrenocorticotropin response to stressors. Endocrinology. 144:2396-2403.

52. Coste, S.C., Murray, S.E., and Stenzel-Poore, M.P. 2001. Animal models of CRH excess and CRH receptor deficiency display altered adaptations to stress. Peptides. 22:733-741.

53. Taché, Y., and Million, M. 2006. Central corticotropin-releasing factor and the hypothalamic-pituitary-adrenal axis in gastrointestinal physiology. In Physiology of the gastrointestinal tract. L.R. Johnson and J. Wood, editors. Academic Press. Burlington,
Massachusetts, USA. 791-816.

54. Kihara, N., et al. 2001. Effects of central and peripheral urocortin on fed and fasted gastroduodenal motor activity in conscious rats. Am. J. Physiol. Gastrointest. Liver Physiol. 280:G406-G419.

55. Lee, C., and Sarna, S.K. 1997. Central regulation of gastric emptying of solid nutrient meals by corticotropin releasing factor. Neurogastroenterol. Motil. 9:221-229.

56. Martinez, V., Wang, L., Rivier, J., Grigoriadis, D. and Taché, Y. 2004. Central CRF, urocortins and stress increase colonic transit via CRF1 receptors while activation of CRF2 receptors delays gastric transit in mice. J. Physiol. 556:221-234.

57. Czimmer, J., Million, M., and Taché, Y. 2006. Urocortin 2 acts centrally to delay gastric emptying through sympathetic pathways while CRF and urocortin 1 inhibitory actions are vagal dependent in rats. $A m$. J. Physiol. Gastrointest. Liver Physiol. 290:G511-G518.

58. Chen, C.Y., et al. 2002. Intracisternal urocortin inhibits vagally stimulated gastric motility in rats: role of CRF(2). Br. J. Pharmacol. 136:237-247.

59. Lewis, M.W., Hermann, G.E., Rogers, R.C., and Travagli, R.A. 2002. In vitro and in vivo analysis of the effects of corticotropin releasing factor on rat dorsal vagal complex. J. Physiol. 543:135-146.

60. Bittencourt, J.C., and Sawchenko, P.E. 2000. Do centrally administered neuropeptides access cognate receptors?: an analysis in the central corticotropinreleasing factor system. J. Neurosci. 20:1142-1156.

61. Lenz, H.J., Burlage, M., Raedler, A., and Greten, H. 1988. Central nervous system effects of corticotropin-releasing factor on gastrointestinal transit in the rat. Gastroenterology. 94:598-602.

62. Taché, Y., Maeda-Hagiwara, M., and Turkelson, C.M. 1987. Central nervous system action of corticotropin-releasing factor to inhibit gastric emptying in rats. Am. J. Physiol. 253:G241-G245.

63. Nakade, Y., et al. 2005. Restraint stress delays solid gastric emptying via a central CRF and peripheral sympathetic neuron in rats. Am. J. Physiol. Regul. Integr. Comp. Physiol. 288:R427-R432.

64. Mönnikes, H., Schmidt, B.G., Raybould, H.E., and Taché, Y. 1992. CRF in the paraventricular nucleus mediates gastric and colonic motor response to restraint stress. Am. J. Physiol. 262:G137-G143.

65. Gué, M., Fioramonti, J., Frexinos, J., Alvinerie, M., and Buéno, L. 1987. Influence of acoustic stress by noise on gastrointestinal motility in dogs. Dig. Dis. Sci. 32:1411-1417.

66. Lenz, H.J., Raedler, A., Greten, H., Vale, W.W., and Rivier, J.E. 1988. Stress-induced gastrointestinal secretory and motor responses in rats are mediated by endogenous corticotropin-releasing factor. Gastroenterology. 95:1510-1517.

67. Bonaz, B., Plourde, V., and Taché, Y. 1994. Abdominal surgery induces Fos immunoreactivity in the rat brain. J. Comp. Neurol. 349:212-222.

68. Barquist, E., et al. 1996. Neuronal pathways involved in abdominal surgery-induced gastric ileus in rats. Am. J. Physiol. 270:R888-R894.

69. Harbuz, M.S., and Lightman, S.L. 1989. Responses of hypothalamic and pituitary mRNA to physical and psychological stress in the rat. J. Endocrinol. 122:705-711.

70. Rivest, S., and Rivier, C. 1994. Stress and interleukin-1 beta-induced activation of c-fos, NGFI-B and CRF gene expression in the hypothalamic PVN: comparison between Sprague-Dawley, Fisher-344 and Lewis rats. J. Neuroendocrinol. 6:101-117.

71. Tanaka, Y., et al. 2003. Effect of stress and adrenalectomy on urocortin II mRNA expression in the hypothalamic paraventricular nucleus of the rat. Neuroendocrinology. 78:1-11.

72. Korosi, A., Schotanus, S., Olivier, B., Roubos, E.W., and Kozicz, T. 2005. Chronic ether stressinduced response of urocortin 1 neurons in the Edinger-Westphal nucleus in the mouse. Brain Res.
1046:172-179.

73. Luckey, A., et al. 2003. Corticotropin-releasing factor receptor 1-deficient mice do not develop postoperative gastric ileus. Gastroenterology. 125:654-659.

74. Luckey, A., Livingston, E., and Taché, Y. 2003. Mechanisms and treatment of postoperative ileus. Arch. Surg. 138:206-214.

75. Bueno, L., and Fioramonti, J. 1986. Effects of corticotropin-releasing factor, corticotropin and cortisol on gastrointestinal motility in dogs. Peptides. 7:73-77.

76. Kellow, J.E., Langeluddecke, P.M., Eckersley, G.M., Jones, M.P., and Tennant, C.C. 1992. Effects of acute psychologic stress on small-intestinal motility in health and the irritable bowel syndrome. Scand. J. Gastroenterol. 27:53-58.

77. Wittmann, T., et al. 1990. Long-duration stress. Immediate and late effects on small and large bowel motility in rat. Dig. Dis. Sci. 35:495-500.

78. Williams, C.L., Villar, R.G., Peterson, J.M., and Burks, T.F. 1988. Stress-induced changes in intestinal transit in the rat: a model for irritable bowel syndrome. Gastroenterology. 94:611-621.

79. Taché, Y. 2002. The parasympathetic nervous system in the pathophysiology of the gastrointestinal tract. In Handbook of the autonomic nervous system in health and disease. C.L. Bolis, J. Licinio, and S. Govoni, editors. Marcel Dekker Inc. New York, New York, USA. 463-503.

80. Bonaz, B., and Taché, Y. 1994. Water-avoidance stress-induced c-fos expression in the rat brain and stimulation of fecal output: role of corticotropinreleasing factor. Brain Res. 641:21-28.

81. Mönnikes, H., Schmidt, B.G., Tebbe, J., Bauer, C., and Taché, Y. 1994. Microinfusion of corticotropin releasing factor into the locus coeruleus/subcoeruleus stimulates colonic motor function in rats. Brain Res. 644:101-108.

82. Martinez, V., Rivier, J., Wang, L., and Taché, Y. 1997. Central injection of a new corticotropinreleasing factor (CRF) antagonist, astressin, blocks CRF- and stress-related alterations of gastric and colonic motor function. J. Pharmacol. Exp. Ther. 280:754-760.

83. Miyata, K., Ito, H., and Fukudo, S. 1998. Involvement of the 5-HT3 receptor in CRH-induced defecation in rats. Am. J. Physiol. 274:G827-G831.

84. Gué, M., Tekamp, A., Tabis, N., Junien, J.L., and Bueno, L. 1994. Cholecystokinin blockade of emotional stress- and CRF-induced colonic motor alterations in rats: role of the amygdala. Brain Res. 658:232-238.

85. Jiménez, M., and Buéno, L. 1990. Inhibitory effects of neuropeptide Y (NPY) on CRF and stressinduced cecal motor response in rats. Life Sci. 47:205-211.

86. Million, M., Wang, L., Martinez, V., and Taché, Y. 2000. Differential Fos expression in the paraventricular nucleus of the hypothalamus, sacral parasympathetic nucleus and colonic motor response to water avoidance stress in Fischer and Lewis rats. Brain Res. 877:345-353.

87. Mönnikes, H., Schmidt, B.G., and Taché, Y. 1993. Psychological stress-induced accelerated colonic transit in rats involves hypothalamic corticotropinreleasing factor. Gastroenterology. 104:716-723.

88. Lu, L., Liu, D., Ceng, X., and Ma, L. 2000. Differential roles of corticotropin-releasing factor receptor subtypes 1 and 2 in opiate withdrawal and in relapse to opiate dependence. Eur. J. Neurosci. 12:4398-4404.

89. Martinez, V., and Taché, Y. 2001. Role of CRF receptor 1 in central CRF-induced stimulation of colonic propulsion in rats. Brain Res. 893:29-35.

90. Bale, T.L., et al. 2002. Mice deficient for both corticotropin-releasing factor receptor 1 (CRFR1) and CRFR2 have an impaired stress response and display sexually dichotomous anxiety-like behavior. 
J. Neurosci. 22:193-199.

91. Valentino, R.J., Miselis, R.R., and Pavcovich, L.A. 1999. Pontine regulation of pelvic viscera: pharmacological target for pelvic visceral dysfunctions. Trends Pharmacol. Sci. 20:253-260.

92. Kresse, A.E., Million, M., Saperas, E., and Taché, Y. 2001. Colitis induces CRF expression in hypothalamic magnocellular neurons and blunts CRF gene response to stress in rats. Am. J. Physiol. Gastrointest. Liver Physiol. 281:G1203-G1213.

93. Sternberg, E.M., et al. 1989. A central nervous system defect in biosynthesis of corticotropin-releas ing hormone is associated with susceptibility to streptococcal cell wall-induced arthritis in Lewis rats. Proc. Natl. Acad. Sci. U. S. A. 86:4771-4475.

94. Bonaz, B., and Rivest, S. 1998. Effect of a chronic stress on CRF neuronal activity and expression of its type 1 receptor in the rat brain. Am. J. Physiol. 275:R1438-R1449.

95. Reyes, B.A., Valentino, R.J., Xu, G., and Van Bockstaele, E.J. 2005. Hypothalamic projections to locus coeruleus neurons in rat brain. Eur. J. Neurosci. 22:93-106.

96. Koob, G.F. 1999. Corticotropin-releasing factor, norepinephrine, and stress. Biol. Psychiatry. 46:1167-1180.

97. Reyes, B.A., Fox, K., Valentino, R.J., and Van Bockstaele, E.J. 2006. Agonist-induced internalization of corticotropin-releasing factor receptors in noradrenergic neurons of the rat locus coeruleus. Eur. J. Neurosci. 23:2991-2998.

98. Folks, D.G. 2004. The interface of psychiatry and irritable bowel syndrome. Curr. Psychiatry Rep. 6:210-215.

99. Taché, Y., Garrick, T., and Raybould, H. 1990. Central nervous system action of peptides to influence gastrointestinal motor function. Gastroenterology. 98:517-528

100. Chatzaki, E., et al. 2004. Differential profile of CRF receptor distribution in the rat stomach and duodenum assessed by newly developed CRF receptor antibodies. J. Neurochem. 88:1-11.

101. Chatzaki, E., et al. 2004. CRF receptor type 1 and 2 expression and anatomical distribution in the rat colon. J. Neurochem. 90:309-316.

102.Porcher, C., Juhem, A., Peinnequin, A., Sinniger V., and Bonaz, B. 2005. Expression and effects of metabotropic CRF1 and CRF2 receptors in rat small intestine. Am. J. Physiol. Gastrointest. Liver
Physiol. 288:G1091-G1103.

103. Muramatsu, Y., et al. 2000. Urocortin and corticotropin-releasing factor receptor expression in the human colonic mucosa. Peptides. 21:1799-1809.

104.Liu, S., et al. 2005. Expression of type 1 corticotropin-releasing factor receptor in the guinea pig enteric nervous system. J. Comp. Neurol. 481:284-298.

105.Porcher, C., et al. 2006. Endogenous expression and in vitro study of CRF-related peptides and CRF receptors in the rat gastric antrum. Peptides. 27:1464-1475.

106.Martinez, V., Wang, L., Rivier, J.E., Vale, W., and Taché, Y. 2002. Differential actions of peripheral corticotropin-releasing factor (CRF), urocortin II, and urocortin III on gastric emptying and colonic transit in mice: role of CRF receptor subtypes 1 and 2 . J. Pharmacol. Exp. Ther. 301:611-617.

107.Pappas, T., Debas, H., and Taché, Y. 1985. Corticotropin-releasing factor inhibits gastric emptying in dogs. Regul. Pept. 11:193-199.

108.Fukudo, S., Nomura, T., and Hongo, M. 1998. Impact of corticotropin-releasing hormone on gastrointestinal motility and adrenocorticotropic hormone in normal controls and patients with irritable bowel syndrome. Gut. 42:845-849.

109.Mayer, E.A., Sytnik, B., Reddy, N.S., Van Deventer, G., and Taché, Y. 1992. Corticotropin releasing factor (CRF) increases post-prandial duodenal motor activity in humans. Journal of Gastrointestinal Motility. 4:53-60.

110.Taché, Y. 1999. Cyclic vomiting syndrome: the corticotropin-releasing-factor hypothesis. Dig. Dis. Sci. 44:79S-86S

111. Martinez, V., Rivier, J., and Taché, Y. 1999. Peripheral injection of a new corticotropin-releasing factor (CRF) antagonist, astressin, blocks peripheral CRF-and abdominal surgery-induced delayed gastric emptying in rats. J. Pharmacol. Exp. Ther 290:629-634.

112.Million, M., et al. 2002. Human urocortin II, a new CRF-related peptide, displays selective $\mathrm{CRF}_{2}$-mediated action on gastric transit in rats. Am. J. Physiol. Gastrointest. Liver Physiol. 282:G34-G40.

113.Maillot, C., Million, M., Wei, J.Y., Gauthier, A., and Taché, Y. 2000. Peripheral corticotropin-releasing factor and stress-stimulated colonic motor activity involve type 1 receptor in rats. Gastroenterology. 119:1569-1579.

114. Saunders, P.R., Maillot, C., Million, M., and Taché, Y.
2002. Peripheral corticotropin-releasing factor induces diarrhea in rats: role of $\mathrm{CRF}_{1}$ receptor in fecal watery excretion. Eur. J. Pharmacol. 435:231-235.

115.Miampamba, M., Maillot, C., Million, M., and Taché, Y. 2002. Peripheral CRF activates myenteric neurons in the proximal colon through $\mathrm{CRF}_{1}$ receptor in conscious rats. Am. J. Physiol. Gastrointest. Liver Physiol. 282:G857-G865.

116.Bueno, L., et al. 1986. Effects of corticotropinreleasing factor on plasma motilin and somatostatin levels and gastrointestinal motility in dogs. Gastroenterology. 91:884-889.

117. Maillot, C., Wang, L., Million, M., and Taché, Y. 2003. Intraperitoneal corticotropin-releasing factor and urocortin induce Fos expression in brain and spinal autonomic nuclei and long lasting stimulation of colonic motility in rats. Brain Res. 974:70-81.

118.Raybould, H.E., Koelbel, C.B., Mayer, E.A., and Taché, Y. 1990. Inhibition of gastric motor function by circulating corticotropin-releasing factor in anesthetized rats. Journal of Gastrointestinal Motility. 2:265-272.

119.Mancinelli, R., Azzena, G.B., Diana, M., Forgione, A., and Fratta, W. 1998. In vitro excitatory actions of corticotropin-releasing factor on rat colonic motility. J. Auton. Pharmacol. 18:319-324.

120.Nozu, T., Martinez, V., Rivier, J., and Taché, Y. 1999. Peripheral urocortin delays gastric emptying: role of CRF receptor 2. Am. J. Physiol. 276:G867-G875.

121.Barquist, E., Zinner, M., Rivier, J., and Taché, Y. 1992. Abdominal surgery-induced delayed gastric emptying in rats: role of CRF and sensory neurons. Am. J. Physiol. 262:G616-G620.

122.Castagliuolo, I., et al. 1996. Acute stress causes mucin release from rat colon: role of corticotropin releasing factor and mast cells. Am. J. Physiol. 271:G884-G892.

123.Kozicz, T., and Arimura, A. 2002. Distribution of urocortin in the rat's gastrointestinal tract and its colocalization with tyrosine hydroxylase. Peptides. 23:515-521.

124.Harada, S., et al. 1999. Urocortin mRNA is expressed in the enteric nervous system of the rat. Neurosci. Lett. 267:125-128.

125.Zobel, A.W., et al. 2000. Effects of the high-affinity corticotropin-releasing hormone receptor 1 antagonist R121919 in major depression: the first 20 patients treated. J. Psychiatr. Res. 34:171-181. 